\title{
Keefektifan Model Pembelajaran Cooperative Integrated Readinng and Composition (CIRC) Berbantuan Electronic Book (E-Book) Terhadap Hasil Belajar Menulis Karya Ilmiah dan peningkatan Karakter Mahasiswa PGSD Universitas Negeri Semarang
}

\author{
Hartati \\ Program Studi Pendidikan Guru SD, Universitas Negeri Semarang, \\ hartati@mail.unnes.ac.id
}

\begin{abstract}
Abstrak
Tujuan penelitian ini adalah menghasilkan model pembelajaran CIRC berbantuan ebook, menguji tingkat efektivitas model pembelajaran CIRC berbantuan e-book dalam mengembangkan karakter, meningkatkan aktivitas dan hasil belajar mahasiswa, serta mendeskripsikan respon mahasiswa terhadap model pembelajaran CIRC berbantuan e-book, dalam perkuliahan Bahasa Indonesia di PGSD Universitas Negeri Semarang. Metode penelitian ini adalah quasi eksperimen dengan subyek mahasiswa S1 PGSD FIP UNNES yang menempuh mata kuliah Bahasa Indonesia pada tahun akademik 2014/2015. Teknik pengambikan sampel menggunakan teknik Randomized Group Assignment". Hasil penelitian ini adalah: 1) Dengan mengontrol variabel inteligensi dan pengetahuan awal, model pembelajaran CIRC berbantuan e-book lebih efektif daripada model pembelajaran konvensional dalam mengembangkan karakter dalam perkuliahan Bahasa Indonesia, dimana $\mathrm{F}$ hitung $(\mathrm{Fo})=1,385$ dan $\mathrm{F}$ probabilitas $(\mathrm{Fp})=0,256$ (2) Dengan mengontrol variabel inteligensi dan pengetahuan awal, model pembelajaran CIRC berbantuan e-book lebih efektif daripada model pembelajaran konvensional dalam meningkatkan hasil belajar mahasiswa dalam perkuliahan Bahasa Indonesia dimana $\mathrm{F}$ hitung $(\mathrm{Fo})=14,571$ dan $\mathrm{F}$ probabilitas $(\mathrm{Fp})=0,028$; (5) Sejumlah 88,89\% mahasiswa PGSD Universitas Negeri Semarang memiliki respon yang sangat baik terhadap model pembelajaran CIRC berbantuan e-book.
\end{abstract}

Kata Kunci: CIRC, e-books, karakter, menulis karya ilmiah

\section{Abstract}

The purpose of this study was to (1) test the effectiveness of the CIRC model (2) to test the effectiveness of the learning CIRC model assisted e-book to improving the skills, activity and learnig outcome of students in Elementary School Teacher Education, (3) describe the response of students to CIRC model assisted e-books in Indonesian lesson of Elementary School Teacher Education in Semarang State University. The method of research was quasiexperimental. The study population was students of Elementary School Teacher Education who take Indonesian lesson in academic year 2014/2015. Determination of the study sample, using Randomized Group Assigment. The results showed: (1) with control the intelligence variable and initial knowledge, CIRC model assisted electronic book (e-book) effectively to develop the character of students who take Indonesian lesson, where $F$ arithmetic $(F o)=1,385$ and $F$ probability $(F p)=0.256$; (2) by controlling the variables of intelligence and initial knowledge, CIRC model assisted e-book is more effective than conventional learning models to improve the learning outcomes of students in Elementary School Teacher Education to writing scientific papers with $F$ arithmetic $(F o)=14.571$ and $F$ probability $(F p)=0.028$; (3) The amount of 88.89\% students in Elementary School Teacher Education of Semarang State University has a very good response (scale 3 and 4 is greater than the scale 1 and 2) of the CIRC model assisted electronic book (e-book).

Keywords: CIRC, e-books, characters, writing scientific papers. 


\section{PENDAHULUAN}

Menulis pada hakikatnya adalah upaya mengekspressikan apa yang dilihat, dialami, dirasakan, dan dipikirkan ke dalam bahasa tulisan. Menurut Tarigan ( 2008:3) menulis merupakan suatu keterampilan berbahasa yang dipergunakan untuk berkomunikasi secara tidak langsung, tidak secara tatap muka dengan orang lain. Sedangkan Suparno dan Yunus (2009:1.3) mengemukakan bahwa menulis adalah suatu kegiatan penyampaian pesan dengan bahasa tulis sebagai alat atau medianya. Melalui kegiatan menulismahasiswa dapat menuangkan ide dan gagasannya serta mengembangkan daya berpikir kreatif dalam mengemukakan segala informasi yang dimilikinya dalam bentuk tulisan.

Di dalam kehidupan modern semua orang membutuhkan kemampuan menulis, termasuk ibu rumah tangga. Kebutuhan menulis sangat dirasakan oleh para intelektual seperti guru, dosen, peneliti termasuk mahasiswa. Bagi mahasiswa menulis tidak hanya kebutuhan, tetapi merupakan keharusan. Sebelum menyelesaikan studinya, setiap mahasiswa diwajibkan menulis, misalnya menulis ringkasanbuku, menulis makalah, atau menulis laporan. Menulis yang dilakukan oleh para profesional ini biasa dinamakan menulis karya ilmiah

Karya ilmiah adalah suatu karya yang memuat dan mengkaji suatu masalah tertentu dengan menggunakan kaidah - kaidah keilmuan. Maksudnya karya ilmiah ini dalam membahas masalah maupun menyajikan kajiannya menggunakan metode ilmiah, menggunakan tatatulis ilmiah dan menggunakan bahasa baku. Di samping itu karya ilmiah juga menggunakan prinsip-prinsip keilmuan yang lain seperti objektif, logis, empiris, sistematis, lugas, jelas dan konsisten. Berdasarkan penjelasan di atas maka menulis karya ilmiah sebenarnya merupakan sebuah proses kreatif yang dilaksanakan dengan melibatkan aktivitas berfikir dan penuangan gagasan ke dalam tulisan dengan menerapkan berbagai konvensi penulisan. Secara umum karya ilmiah didefinisikan sebagai tulisan yang mengungkapkan buah pikiran yang diperoleh dari hasil pengamatan ,penelitian, atau peninjauan terhadap sesuatu yangdisusun menurut metode dan sistematika tertentu, danyang isi serta kebenarannya dapatdipertanggungjawabkan.Batasan ini didukung olehDay (Djuroto dan Bambang (2003:12-13) yang menyatakan bahwa karya tulis ilmiah merupakansuatu tulisan yang memaparkan hasilpenyelidikan, pengamatan, pengumpulan data yang didapat dari suatu penelitian, baik penelitian lapangan, tes laboratorium ataupun kajianpustaka.Keduadefinisi inimenegaskan bahwayang dipaparkan dalam karya ilmiah adalah hasil penelitian atau pengkajian yang dilakukan oleh seseorang atau sebuah tim.

Menurut Iskandarwassid (2008) kemampuan menulis lebih sulit dikuasai karena dalam membuat sebuah tulisan, penulis diharuskan untuk menguasai berbagai unsur kebahasaan dan unsur di luar bahasa itu sendiri. Hal ini dialami oleh mahasiswa PGSDketika mendapatkan tugas menulis karangan, tidak semua mampu menulis dengan baik.

Menurut pengamatan peneliti, salah satu pembelajaran yang perlu mendapat perhatian di PGSD UNNES adalah pembelajaran dalam kelompok MKU (Mata Kuliah 
Umum), khususnya mata kuliah Bahasa Indonesia. Perlunya peningkatan kualitas pembelajaran mata kuliah Bahasa Indonesia dilihat dari tujuan MKU Bahasa Indonesia, yang menyiapkan mahasiswa memiliki seperangkat kompetensi profesional, khususnya menguasai materi Bahasa Indonesia untuk menjadi guru yang professional. Selain itu mata kuliah Bahasa Indonesia merupakan mata kuliah yang membekali mahasiswa dengan pengetahuan dan keterampilan menyimak, berbicara, membaca, dan menulis, yang mempunyai peran penting didalam komunikasi baik secara lisan maupun tulisan, serta penguatan karakter mahasiswa. Bahasa seseorang mencerminkan karakter dan pikirannya, semakin terampilseseorang berbahasa, semakin cerah dan jelas jalan pemikirannya.Di sisi lain, berdasarkan observasi peneliti selama menjadi dosen MKUmata kuliah Bahasa Indonesia di PGSD, diperoleh fakta bahwa proses pembelajaran Bahasa Indonesia selama ini masih terkesan hanya berpusat pada dosen (teacher oerinted) mahasiswa hanya menerima apa yang diberikan oleh dosen, sehingga ceramah merupakan satu-satunya pilihan yang dianggap paling cocok dalam strategi pembelajaran. Proses yang dibangun oleh dosen cenderung terbatas pada penguasaan materi,Sehingga hasilnya cenderung pada penguatan kognitif saja, pengembangan karakter masih kurang. Perkuliahan MKU, khususnya Bahasa Indonesia, didominasi pendekatan ekspositoris, akibatnya Bahasa Indonesia dianggap mata kuliah hapalan yang tidak menantang mahasiswa untuk berpikir. Pembelajaran mata kuliah Bahasa Indonesia yang dilakukan selama ini cenderung hanya memperhatikan jumlah pokok bahasan dan alokasiwaktu yang tersedia, dengan mengejar ketercapaian kurikulum tanpa mempertimbangkan beberapa hal penting yang telah digariskan oleh kurikulum. Hal inilah yang menyebabkan hasil pembelajaran kurang sesuai dengan harapan, karena mahasiswa memperoleh pengetahuan secara teoretis dan bertindak pasif. Dengan keadaan yang seperti itu maka peneliti mencoba menggunakan strategi pembelajaran kooperatif.

Pembelajaran kooperatif merupakan pembelajaran yang berfokus padapenggunaan kelompok kecil peserta didik untuk bekerja sama dalam memaksimalkankondisi belajar untuk mencapai tujuan belajar.Dengan pembelajaran kooperatif, interaksi yang terjadidi dalam kelompok dapat melatih dan memperkuat karakter peserta didik untuk bersikap demokratis, mau menerima dan menghargaipendapat orang lain. Salah satu model pembelajaran kooperatif yang dapat digunakan dalam pembelajaran Bahasa Indonesia adalah tipe Cooperative Integrated Reading andComposition (CIRC). Pembelajaran CIRC adalah komposisi terpadumembaca dan menulis secara kooperatif/kelompok.Dalam CIRC mahasiswadituntut untuk menguasai pikiran utama suatu wacana dan kemampuanmembaca dan menulis lainnya secara bersama-sama. Dosen membentuk kelompok mahasiswa, kemudian menyelesaikan masalah yang terdapat dari bacaansecara bersama-sama.Pembelajaran CIRCdiharapkan dapat meningkatkan caramahasiswa berfikir kritis, kreatif danmenumbuhkan rasa demokratis, serta toleran. Dengan menggunakanpembelajaran CIRC mahasiswa dapat latihan membaca atau saling membaca,memahami ide pokok, menuliskan kembali isi cerita dan memberikantanggapan terhadap isi bacaan yang telah dibaca secara 
berkelompok.Pembelajaran CIRC menghendaki mahasiswa harus aktif dalam proses pembelajaran, tidak hanya sekedar mendengar dan mencatat apa yang diberikan olehdosen, selain itu mahasiswa juga harus mampu mengkontruksi dan membangun pengetahuan baru.

Menurut Abidin (2012:92-93) metode Cooperative Integrated Reading and Composition (CIRC) pada dasarnya bertujuan untuk meningkatkan kemampuan siswa dalam memahami isi bacaan sekaligus membina kemampuan menulis reproduksi atas bahan bacaan yang dibacanya. Metode CIRC juga dapat membantu guru memadukan kegiatan membaca menulis sebagai kegiatan yang integratif dalam pelaksanaan pembelajaran membaca. Sedangkan Slavin (2005:200) menyatakan bahwa metode Cooperative Integrated Reading and Composition (CIRC) merupakan sebuah metode komprehensif yang digunakan untuk mengajarkan pelajaran membaca, menulis, dan seni berbahasa pada kelas yang lebih lebih tinggi di sekolah dasar. Sejalan dengan Abidin dan Slavin, menurut Huda (2016 :126) mengemukakan bahwa metode Cooperative Integrated Reading and Composition (CIRC) merupakan metode yang dirancang untuk mengakomodasi level kemampuan siswa yang beragam, baik melalui pengelompokan heterogen (heterogeneous grouping) maupun pengelompokan homogen (homogeneous grouping). Dalam metode tersebut siswa ditempatkan dalam kelompokkelompok kecil, baik homogen maupun heterogen.

Model pembelajaran CIRC yang diterapkandi dalam penelitian digabungkan dengan e-book (electronic book) sebagai salah satu bentuk pemanfaatan TIK dalam pembelajaran. Buku elektronik atau e-book adalah salah satu teknologi yang memanfaatkan komputer untuk menayangkan informasi multimedia dalam bentuk yang ringkas dan dinamis. Model pembelajaran CIRC berbantuan electronic book(e-book) diimplementasikan melalui cooperative learningdengan pemecahan masalah dalam kelompok dan menggunakan electronic book (e-book) sebagai media dan sumber belajar. Dalam pembelajaran Cooperative Integrated Reading and Composition (CIRC) berbantuan electronic book (e-book)ini kelas dibagi dalam kelompok-kelompok kecil, para mahasiswa diberi suatu teks / bacaan (bahan ajar), kemudian mahasiswa latihan membaca atau saling membaca, memahami ide pokok, saling merevisi, dan menulis ringkasan bacaan (bahan ajar) atau memberikan tanggapan terhadap isi bacaan (bahan ajar), atau untuk mempersiapkan tugas tertentu dari dosen, kemudian dengan metode pemecahan masalah menghadapkan mahasiswa kepada suatu masalah agar dipecahkan, dengan menggunakan komputer sebagai media dan atau sumber belajar. Mengkombinasikan antara pembelajaran Cooperative Integrated Reading and Composition (CIRC) berbantuan electronic book (e-book), diasumsikan dapat meningkatkan kemampuan berpikir mahasiswa dalam memecahkan masalah, memperkuat karakter, serta kualitas pembelajaran secara positip. Berdasarkan pemikiran dan kondisi tersebut di atas, penelitian ini mencoba menguji keefektifan model pembelajaran Cooperative Integrated Reading and Composition (CIRC) berbantuan electronic book (e-book) untuk mengembangkan karakter serta meningkatkan keterampilan menulis mahasiswa PGSD UNNES. 
Tujuan penelitian ini untuk : (1) menguji keefektifan model pembelajaran Cooperative Integrated Reading and Composition (CIRC) berbantuan electronic book (e-book) dalam mengembangkan karakter di dalam perkuliahan di PGSD Universitas Negeri Semarang, (2) menguji keefektifan model pembelajaran Cooperative Integrated Reading and Composition (CIRC) berbantuan electronic book (e-book) dalam meningkatkan hasil belajar perkuliahan Bahasa Indonesia di PGSD Universitas Negeri Semarang, (3) mendeskripsikan respon mahasiswa terhadap model pembelajaran Cooperative IntegratedReading and Composition (CIRC) berbantuan electronic book (e-book)dalam perkuliahan Bahasa Indonesia di PGSD Universitas Negeri Semarang.

Di dalam penelitian ini untuk mengukur hasil belajar / prestasi belajar digunakan klasifikasi domain dari Bloom. Hasil belajar yang dimaksud dalam penelitian ini adalah hasil belajar mahasiswa di dalam mata kuliah Bahasa Indonesia untuk ranah kognitif dan keterampilan menulis deskriptif yang dinyatakan secara kuantitatif berdasarkan hasil pengukuran atau tes hasil belajar. Dalam penelitian ini yang dimaksud dengan keterampilan menulis deskripsi adalah kemampuan menggunakan bahasa secara tertulis untuk menyampaikan atau memberikan perincian-perincian dari objek tertentu yang diukur dari aspek 1) isi tulisan, 2) organisasi isi, 3) tata bahasa; 4) diksi, 5) ejaan dan tanda baca; 6) kerapian tulisan.

Menurut Suyanto (2012), karakter adalah cara berpikir dan berperilaku yang menjadi ciri khas tiap individu untuk hidup dan bekerjasama, baik dalam lingkup keluarga, masyarakat, bangsa dan negara. Individu yang berkarakter baik adalah individu yang bisa membuat keputusan dan siap bertanggungjawab terhadap akibat keputusanyang dibuat (http://mandikdasmen.kemdiknas.go.id).Dalam konteks pendidikan, ada banyak nilai karakter yang perlu ditanamkan dalam diri peserta didik. Nilai-nilai yang diinternalisasikan adalah yang berkaitan dengan Olah Hati (Spiritual and emotional development), Olah Pikir (intellectual development), Olah Raga dan Kinestetik (Physical and kinestetic development), dan Olah Rasa dan Karsa (Affective and Creativity development).Dalam penelitian ini karakter diartikan sebagai pola berpikir dan berperilaku yang menjadi kebiasaan seseorang sebagai ciri khas tiap seseorang dalam kehidupan sosial, dan melakukan komunikasi dengan Tuhan, diri sendiri, keluarga, masyarakat, dan alam sekitarnya, yang indikatornya mencakupi(1) toleransi, (2) disiplin, (3) kerja keras, (4) kreatif, (5) demokratis, (6) bersahabat, (7) gemar membaca, (8) peduli sosial, serta (9) tanggung jawab.

Menurut Gunter et al (1990:67), an instructional model is a step-by-step procedure that leads to specific learning outcomes.Pembelajaran Cooperative Integrated Reading and Composition (CIRC) atau pembelajaran Kooperatif Terpadu Membaca dan Menulis, merupakan model pembelajaran dalam rangka membaca dan menemukan ide pokok, pokok pikiran atau,tema sebuah bacaan. Model pembelajaran Cooperative Integrated Reading and Composition (CIRC) ini dapat dikategorikan pembelajaran cooperative (Slavin, 2005).Menurut Slavin (2005), model pembelajaran CIRC memiliki 8 komponen, yaitu : (1) teams, (2) placement test, (3) student creative, (4) team study, (5) team scorer and team recognition, (6) teaching group, (7) facts tes, (8) whole-class 
units. Pembelajaran berbantuanelectronic book (E-book) adalah pembelajaran dengan memanfaatkanelectronic book (e-book) sebagai media pembelajaran dan sumber belajar, dengan menggunakan komputer dan piranti lunak (soft file) dalam rangka untuk membelajarkan mahasiwa dan untuk memenuhi kebutuhan mahasiswa dalam mencapai tujuan pembelajaran yaitu dengan memecahkan masalah.Model Pembelajaran CIRC berbantuan electronic book (e-book) adalah pembelajaran melalui cooperative learning, dengan memecahkan masalah dalam kelompok, serta menggunakan e-book sebagai media dan sumber belajar. Dalam pembelajaran Cooperative Integrated Reading and Composition (CIRC) berbantuan e-bookini mahasiswa di kelas dibentuk dalam kelompok-kelompok kecil, para mahasiswa diberi suatu teks bacaan, ( bahan ajar) kemudian mahasiswa latihan membaca atau saling membaca, memahami ide pokok, saling merevisi, dan menulis ringkasanbacaan (bahan ajar) atau memberikan tanggapan terhadap isi bacaan (bahan ajar), atau untuk mempersiapkan tugas tertentu dari dosen, kemudian dengan metode pemecahan masalah, menghadapkan mahasiswa kepada suatu masalah agar dipecahkan, dengan menggunakan komputer sebagai media dan sumber belajar. Dengan mengelaborasi pendapat Slavin(2005) dan Agus Suprijono (2009), langkah-langkah model pembelajaran Cooperative Integrated Reading and Composition (CIRC) berbantuan e-book, adalah sebagai berikut : (1) fase orientasi, (2) fase organisasi, (3) fase pengenalan konsep, (4) fase eksplorasi dan aplikasi, (5) fase publikasi, (6) fase penguatan dan refleksi, (7) evaluasi.

\section{METODE}

Jenis penelitian ini menggunakan penelitian eksperimen. Desain penelitiannya adalah quasi experimental design bentuk Nonequivalent Control Group Design.Lokasi penelitiannya di PGSD FIP Universitas Negeri Semarang.Populasi penelitian ini adalah mahasiswa S1 PGSD FIP UNNES yang menempuh mata kuliah Bahasa Indonesia pada tahun akademik 2014/2015. Untuk penentuan sampel penelitian, digunakan teknik pengacakan kelompok penugasan atau "Randomized Group Assignment". Sampel penelitian ini dibagi menjadi dua unit. Unit pertama terdiri dari mahasiswa rombel 49 sebagai kelompok kontrol yang dikenai model pembelajaran konvensional dengan jumlah subyek 45 orang, dan unit 3 terdiri dari mahasiswa rombel 24 sebagai kelompok eksperimen yang dikenai model pembelajaran CIRC berbantuan e-book dengan jumlah subyek 45 orang. Variabel penelitian ini mencaliputi : 1) model pembelajaran CIRC berbantuan e-book, 2) karakter, 3) hasil belajar Bahasa Indonesia, berupa keterampilan menulis. Teknik pengumpulan data menggunakan : (1) angket, (2) wawancara, (3) studi dokumentasi, (4) observasi, (5) Skala Sikap Kepribadian, (6) TesPrestasi Belajar, (7) Tes Standard Progressive Matrics (SPM) buatan Raven. Sebelum intrumen digunakan untuk mengambil data, terlebih dahulu dilakukan analisis perangkat tes yaitu uji validitas, reliabilitas, taraf kesukaran, dan daya pembeda. Teknik analisis data menggunakan (1) teknik delphi, (2) analisis deskriptif, (3) analisis uji perbedaan mean (t-test), (4) analisis kualitatif, (5) Analisis Kovarians 


\section{HASIL DAN PEMBAHASAN}

Model pembelajaran CIRC berbantuan e-book efektif untuk mengembangkan karakter danmeningkatkan hasil belajar menulis karangan ilmiah mahasiswa. Sejumlah 93,33\% mahasiswa yang dikenai model pembelajaran CIRC berbantuan e-book mampu mengembangkan karakter dalam kategori sangat baik, yang indikatornya mencakupi : (1) toleransi, (2) disiplin, (3) kerja keras, (4) kreatif, (5) demokratis, (6) bersahabat, (7) gemar membaca, (8) peduli sosial, serta (9) tanggung jawab. Skor rata-rata pengembangan karakter mahasiswa yang dikenai model pembelajaran CIRC berbantuan e-book adalah 65,4889 artinya sangat baik. Sedangkan skor rata-rata pengembangan karakter mahasiswa yang dikenai model pembelajaran konvensional adalah 57,6222 artinya baik. Dari ujit-test ditemukan koefisien t hitung 16,126 dan t probabilitas = 6,88351 untuk $\mathrm{p}<0,05$. Dengan menggunakan analisis kovarians dengan kovariat inteligensi dan pengetahuan awal diukur dari nilai pengembangan karakter, ditemukan rata-rata skor nilai pengembangan karakter untuk kelompok model pembelajaran konvensional sebesar 57,6222 dan kelompok model pembelajaran CIRC berbantuan ebook sebesar 65,4889. Perbedaan skor nilai pengembangan karaktertersebut ternyata signifikan pada $\mathrm{p}<0,05$, dengan kovariat inteligensi dan pengetahuan awal. Karena $\mathrm{F}$ hitung $(\mathrm{Fo})=1,385$ lebih besar daripada $\mathrm{F}$ probabilitas $(\mathrm{Fp})=0,256$, maka hipotesis alternatif yang menyatakan bahwa "Dengan mengontrol variabel inteligensi dan pengetahuan awal, model pembelajaran CIRC berbantuan e-book lebih efektif daripada model pembelajaran konvensional dalam mengembangkan karakter dalamperkuliahan Bahasa Indonesia di PGSD Universitas Negeri Semarang"diterima.Karena perbedaan skor rata-rata pengembangan karakter antara kelompok yang dikenai model pembelajaran CIRC berbantuan e-book dan model pembelajaran konvensional tersebut signifikan, baik secara uji perbedaan mean, t-test, dan analisis kovarians, maka dapat disimpulkan bahwa model pembelajaran CIRC berbantuan e-book lebih efektif dibandingkan model pembelajaran konvensional dalam mengembangkan karakter. Kondisi seperti ini dimungkinkan karena dengan mengacu kepada karakteristik model pembelajaran CIRC berbantuan e-book yang menerapkan prinsip student centered, kolaboratif, dan konstruktivisme.

Sejumlah 91,11\% mahasiswa yang dikenai model pembelajaran CIRC berbantuan e-book memiliki hasil belajar dalam kategori sangat baik, dalam arti mahasiswa yang dikenai model pembelajaran CIRC berbantuan e-book memiliki penguasaan hasil belajar Bahasa Indonesia sekitar 81,25 - $100 \%$. Skor rata-rata hasil belajar mahasiswa yang dikenai model pembelajaran CIRC berbantuan e-book adalah 84,5111 artinya sangat baik. Sedangkan skor rata-rata hasil belajar mahasiswa yang dikenai model pembelajaran konvensional adalah 72,4667 artinya baik. Dari uji t-test ditemukan koefisien $\mathrm{t}$ hitung 18,341 dan $\mathrm{t}$ probabilitas $=10,72093$ untuk $\mathrm{p}<0,05$. Dengan menggunakan analisis kovarians dengan kovariat inteligensi dan pengetahuan awal diukur dari nilai hasil belajar mahasiswa, ditemukan rata-rata skor nilai hasil belajar mahasiswa untuk kelompok model pembelajaran konvensional sebesar 72,4667; dan kelompok model pembelajaran CIRC berbantuan e-book sebesar 84,5111. 
Perbedaan skor nilai hasil belajar mahasiswa tersebut ternyata signifikan pada $p<0,05$, dengan kovariat inteligensi dan pengetahuan awal. Karena F hitung $(\mathrm{Fo})=14,571$ lebih besar daripada $\mathrm{F}$ probabilitas $(\mathrm{Fp})=0,028$, maka hipotesis alternatif yang menyatakan bahwa "Dengan mengontrol variabel inteligensi dan pengetahuan awal, model pembelajaran CIRC berbantuan e-book lebih efektif daripada model pembelajaran konvensional dalam meningkatkan hasil belajar mahasiswa dalam perkuliahan Bahasa Indonesia di PGSD Universitas Negeri Semarang"diterima. Kadar tingkat efektivitas model pembelajaran CIRCberbantuan e-book dalam meningkatkan hasil belajar dalam perkuliahan Bahasa Indonesia di PGSD Universitas Negeri Semarang adalah 36,26\%. Karena perbedaan skor rata-rata hasil belajar mahasiswa antara kelompok yang dikenai model pembelajaran CIRC berbantuan gambar dan model pembelajaran konvensional tersebut signifikan, baik secara uji perbedaan mean, t-test, dan analisis kovarians, maka dapat disimpulkan bahwa model pembelajaran CIRC berbantuan e-book lebih efektif dibandingkan model pembelajaran konvensional dalam meningkatkan hasil belajar mahasiswa dalam perkuliahan Bahasa Indonesia di PGSD Universitas Negeri Semarang. Kondisi seperti ini dimungkinkan karena : (1) dengan mengacu kepada karakteristik kepada model pembelajaran CIRC berbantuan e-book yang menerapkan prinsip konstruktivisme, kolaboratif, student centered, dan berbasis TIK, mahasiswa secara aktif dan kreatif akan berpikir dan berdiskusi memecahkan persoalan, sehingga pemahaman mahasiswa tentang materi lebih baik, (2) melalui diskusi dan kerjasama dalam kelompok, wawasan mahasiswa tentang suatu konsep akan berkembang dan mendapat pengayaan materi, sehingga pengetahuan mahasiswa akan lebih baik.

Sejumlah 88,89\% mahasiswa PGSD Universitas Negeri Semarang memiliki respon yang sangat baik (skala 3 dan 4 lebih besar dibanding skala 1 dan 2) terhadap model pembelajaran CIRC berbantuan e-book dalam perkuliahan Bahasa Indonesia di PGSD Universitas Negeri Semarang, artinya memiliki sikap yang sangat positip dan sangat setuju terhadap model pembelajaran CIRC berbantuan e-book yang indikatornya mencakupi persepsi, sikap penerimaan, sikap persetujuan, sikap kecocokan, minat, dan motivasi. Skor rata-rata respon mahasiswa PGSD Universitas Negeri Semarang terhadap model pembelajaran CIRC berbantuan e-book dalam perkuliahan Bahasa Indonesia di PGSD Universitas Negeri Semarangadalah34,5333 artinya sangat baik. Hal ini dimungkinkan karena dengan mengacu kepada karakteristik model pembelajaran CIRC berbantuan e-book yang menerapkan yang menerapkan prinsip konstruktivime, kolaboratif, student centered, dan pemanfaatan teknologi komputer dan internet dalam pembelajaran, interaksi yang terbuka dan demokratis, membuat mahasiswa senang dan nyaman dalam belajar, sehingga respon mereka menjadi positip terhadap model pembelajaran CIRC berbantuan e-book.

\section{KESIMPULAN}

Simpun penelitian ini adalah sebagai berikut : (1) Sejumlah 93,33\% mahasiswa yang dikenai model pembelajaran CIRC berbantuan e-book mampu mengembangkan karakter dalam kategori sangat baik. Skor rata-rata pengembangan karakter mahasiswa 
yang dikenai model pembelajaran CIRC berbantuan e-book adalah 65,4889 artinya sangat baik.; dan yang dikenai model pembelajaran konvensional adalah 57,6222 artinya baik. Perbedaan skor nilai pengembangan karakter tersebut ternyata signifikan pada $\mathrm{p}<0,05$, dengan koefisien $\mathrm{t}$ hitung 16,126 dan $\mathrm{t}$ probabilitas $=6,88351$. Dengan mengontrol variabel inteligensi dan pengetahuan awal, model pembelajaran CIRC berbantuan e-book lebih efektif daripada model pembelajaran konvensional dalam mengembangkan karakter dalam perkuliahan Bahasa Indonesia di PGSD Universitas Negeri Semarang, dimana $F$ hitung $(\mathrm{Fo})=1,385$ dan F probabilitas $(\mathrm{Fp})=0,256$. Jadi, model pembelajaran CIRC berbantuan e-book lebih efektif dibandingkan model pembelajaran konvensional dalam mengembangkan karakter dalam perkuliahan Bahasa Indonesia di PGSD Universitas Negeri Semarang;

(2) Sejumlah 91,11\% mahasiswa yang dikenai model pembelajaran CIRC berbantuan e-book memiliki hasil belajar dalam kategori sangat baik. Skor rata-rata hasil belajar mahasiswa yang dikenai model pembelajaran CIRCberbantuan e-book adalah 84,5111 artinya sangat baik. Sedangkan skor rata-rata hasil belajar mahasiswa yang dikenai model pembelajaran konvensional adalah 72,4667 artinya baik. Perbedaan skor nilai aktivitas belajar tersebut ternyata signifikan pada $\mathrm{p}<0,05$ dimana $\mathrm{t}$ hitung $=18,341$ dan $\mathrm{t}$ probabilitas $=10,72093$.

Dengan mengontrol variabel inteligensi dan pengetahuan awal, model pembelajaran CIRC berbantuan e-book lebih efektif daripada model pembelajaran konvensional dalam meningkatkan hasil belajar mahasiswa dalam perkuliahan Bahasa Indonesia di PGSD Universitas Negeri Semarang, dimana $F$ hitung $(\mathrm{Fo})=14,571$ dan $\mathrm{F}$ probabilitas $(\mathrm{Fp})=0,028$. Jadi, model pembelajaran CIRC berbantuan e-book lebih efektif dibandingkan model pembelajaran konvensional dalam meningkatkan hasil belajar mahasiswa dalam perkuliahan Bahasa Indonesia di PGSD Universitas Negeri Semarang. Kadar keefektifan model pembelajaran CIRC berbantuan e-book dalam meningkatkan hasil belajar dalam perkuliahan Bahasa Indonesia di PGSD Universitas Negeri Semarang adalah 36,26\%; (3) Sejumlah 88,89\% mahasiswa PGSD Universitas Negeri Semarang memiliki respon yang sangat baik (skala 3 dan 4 lebih besar dibanding skala 1 dan 2) terhadap model pembelajaran CIRC berbantuan e-book dalam perkuliahan Bahasa Indonesia di PGSD Universitas Negeri Semarang, artinya memiliki sikap yang sangat positip dan sangat setuju terhadap model pembelajaran CIRC berbantuan e-book yang indikatornya meliputi persepsi, sikap penerimaan, sikap persetujuan, sikap kecocokan, minat, dan motivasi. Skor rata-rata respon mahasiswa PGSD Universitas Negeri Semarang terhadap model pembelajaran CIRC berbantuan ebook dalam perkuliahan Bahasa Indonesia di PGSD Universitas Negeri Semarang, adalah 34,5333 artinya sangat baik.

Saran yang diajukan terkait dengan hasil penelitian ini antara lain : (1) untukmengembangkan karakter mahasiswa serta meningkatkan kualitas perkuliahan, khususnya di PGSD UNNES, dosen dapat menggunakan model pembelajaran Cooperative Integrated Reading and Composition (CIRC) berbantuan e-book. sebagai salah satu model pembelajaran; (2) untuk menggunakan model pembelajaran 
Cooperative Integrated Reading and Composition (CIRC) berbantuan e-book., dosen perlu berperan sebagai fasilitator, menerapkan teknologi komputer dalam pembelajaran, prinsip belajar kolaboratif dn konstrktivisme, interaksi belajar mengajar yang terbuka, multi arah, akrab, dan demokratis; (3) hasil penelitian ini diharapkan dapat menjadi acuan dan bahan penelitian lebih lanjut bagi LPTK, para dosen, dan para guru untuk menerapkan model pembelajaran Cooperative Integrated Reading and Composition (CIRC) berbantuan e-book dalam pembelajaran, guna meningkatkan kualitas pembelajaran.

\section{DAFTAR RUJUKAN}

Bloom, Benyamin S., (1986).Human Characteristics and School Learning. New York : McGraw-Hill Book, Co.

Gunter, M.A., Estes, T.H., \& Schwab, J.H.(1990). Instruction : A models approach. Boston : Allyn and bacon.

Huda, Miftahul. (2013). Model-Model Pengajaran dan Pembelajaran. Yogyakarta: Pustaka Pelajar.

Iskandarwassid.(2008). Model-modelPembelajaran Bahasa dan SastraSunda. Bandung : Wahana KaryaGrafika

Joyce, B., \& Weil, M..(1980). Model of teaching. New Jersey : Prentice Hall Inc.

Sardiman.(2011). Interakasi dan Motivasi Belajar Mengajar. Jakarta : Rajawali Press.

Slavin, R.E.. (2005). Cooperative learning. Boston : Allyn and Bacon.

Suparno, dan Mohamad Yunus.(2010). Keterampilan Dasar Menulis. Jakarta: Universitas Terbuka.

Suprijono, Agus, (2009). Cooperative Learning , Teori \& Aplikasi PAIKEM. Yogyakarta : Pustaka Pelajar.

Sukmadinata. (2008). Metologi Penelitian Pendidikan. Bandung. PT Remaja Rosdakarya

Suyanto.(2012).UrgensiPendidikanKarakter.(Online)Http://mandikdasmen.kemdiknas. go.id

Tarigan, Henry Guntur. (2008). Menulis sebagai Suatu Keterampilan Berbahasa. Bandung: Angkasa. 